


\section{PASsend beweiden}

J. Mosquera, B. Philipsen, C. van Bruggen, C.M. Groenestein, N.W.M. Ogink 
J. Mosquera, B. Philipsen, C. van Bruggen, C.M. Groenestein, N.W.M. Ogink, 2016. PASsend beweiden. Wageningen UR (University \& Research centre) Livestock Research, Livestock Research Rapport 983. http://dx.doi.org/10.18174/394041

\section{Samenvatting}

Beweiding is een PAS (Programmatische Aanpak Stikstof) maatregel om de ammoniakemissies uit de rundveehouderij te reduceren (PAS 2015.08.02). Een voorwaarde is dat alle melk- en kalfkoeien in de stal minimaal 720 uur per kalenderjaar geweid moeten worden. Aan deze maatregel wordt een ammoniakemissiereductie van $5 \%$ toegekend. Deze deskstudie is uitgevoerd om de ammoniakemissiereductie door beweiding te kunnen differentiëren naar beweidingsstrategie met daarbij oog voor de effecten in de gehele mestketen.

\section{Summary UK}

Grazing is a possible measure within PAS (Programmatic Approach Nitrogen) to reduce ammonia emissions from cattle farming (PAS 2015.08.02). In order to be applied, all dairy cows should be grazing for at least 720 hours per year. This measure is being assigned an ammonia emission reduction of $5 \%$. The purpose of this desk study is to identify and quantify the effect of grazing on the ammonia emission from/in perspective of the whole manure chain for different grazing strategies.

(c) 2016 Wageningen UR Livestock Research, Postbus 338, 6700 AH Wageningen, T 0317483953 , E info.livestockresearch@wur.nl, www.wageningenUR.nl/livestockresearch. Livestock Research is onderdeel van Wageningen UR (University \& Research centre).

Livestock Research aanvaardt geen aansprakelijkheid voor eventuele schade voortvloeiend uit het gebruik van de resultaten van dit onderzoek of de toepassing van de adviezen.

Alle rechten voorbehouden. Niets uit deze uitgave mag worden vermenigvuldigd en/of openbaar gemaakt worden door middel van druk, fotokopie, microfilm of op welke wijze dan ook zonder voorafgaande toestemming van de uitgever of auteur.

\& De certificering volgens ISO 9001 door DNV onderstreept ons kwaliteitsniveau. Op al onze onderzoeksopdrachten zijn de Algemene Voorwaarden van de Animal Sciences Group van toepassing. Deze zijn gedeponeerd bij de Arrondissementsrechtbank Zwolle. 


\section{Inhoud}

Inhoud

Woord vooraf $\quad 5$

$\begin{array}{ll}\text { Samenvatting } & 7\end{array}$

$\begin{array}{llr}1 & \text { Inleiding } & 9\end{array}$

$\begin{array}{lr}2 & 10\end{array}$

2.1 Ammoniakemissiebronnen 10

2.2 Ammoniakemissie uit de landbouw: processen en factoren 12

$3 \quad$ Scenario's voor weidegang en berekeningsmethodiek $\quad 15$

$\begin{array}{llr}4 & \text { Resultaten en discussie } & 18\end{array}$

4.1 Beweidingsuren en uitdoving in de stal 18

$\begin{array}{lll}4.2 & \text { Rantsoen (ruweiwit) } & 19\end{array}$

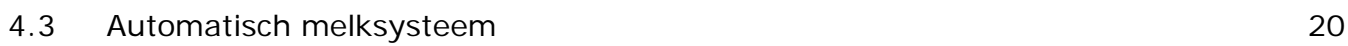

$\begin{array}{llr}5 & \text { Conclusies } & 21\end{array}$

$\begin{array}{ll}\text { Literatuur } & 22\end{array}$

Bijlage $1 \quad \mathrm{NH}_{3}$-emissie voor melk- en kalfkoeien voor alle varianten 23 



\section{Woord vooraf}

Beweiding is een PAS (Programmatische Aanpak Stikstof) maatregel om de ammoniakemissies uit de rundveehouderij te reduceren (PAS 2015.08.02). Een voorwaarde is dat alle melk- en kalfkoeien in de stal minimaal 720 uur per kalenderjaar geweid moeten worden. Aan deze maatregel wordt een ammoniakemissiereductie van $5 \%$ toegekend. Deze deskstudie is uitgevoerd om de ammoniakemissiereductie door beweiding te kunnen differentiëren naar beweidingsstrategie met daarbij oog voor de effecten in de gehele mestketen. Deze studie is uitgevoerd door Wageningen UR Livestock Research in opdracht van ZuivelNL.

Julio Mosquera, projectleider 


\section{Samenvatting}

Beweiding is een PAS (Programmatische Aanpak Stikstof) maatregel om de ammoniakemissies uit de rundveehouderij te reduceren (PAS 2015.08.02). Een voorwaarde bij deze maatregel is dat alle melken kalfkoeien in de stal minimaal 720 uur per kalenderjaar geweid moeten worden. Aan deze maatregel wordt een ammoniakemissiereductie van $5 \%$ toegekend. Deze deskstudie is uitgevoerd om de ammoniakemissiereductie door beweiding te kunnen differentiëren naar beweidingsstrategie met daarbij oog voor de effecten in de gehele mestketen.

Op basis van de berekeningen gerapporteerd in deze deskstudie kunnen de volgende conclusies worden getrokken:

- Het aantal beweidingsuren heeft een duidelijk effect op de ammoniakemissies over de hele mestketen. Het aantal uren weidegang moet wel in balans zijn met de droge stof opname van vers gras en daarmee met de beschikbare beweidingsruimte op het bedrijf. Meer weidegang vraagt een lagere veebezetting per ha, waardoor op intensievere bedrijven meer beweidbare oppervlakte nodig is om de ammoniakreductie te kunnen realiseren.

- De omvang en de duur van het uitdovingseffect op de ammoniakemissie uit de stal als gevolg van het verblijf van dieren in de weide speelt een belangrijke rol bij realiseerbare emissiereductie. Hoe hoger het uitdovingspercentage, hoe hoger de reductie die door beweiding bereikt kan worden.

- De effecten van beweiding in de stal zijn gebaseerd op berekeningen voor een traditioneel huisvestingssysteem met roostervloer. Voor emissiearme-vloeren (die voornamelijk dichte vloeren zijn) is het effect van beweidingsuren op de ammoniakemissie 30-40\% groter dan bij roostervloeren.

- Aanpassingen in het rantsoen (ruweiwit) hebben een direct effect op de ammoniakemissie in de mestketen. Wanneer door aanpassingen in het rantsoen de ruweiwit in het rantsoen toeneemt, zal de TAN (Total Ammonium Nitrogen) in de mest toenemen, en daardoor de $\mathrm{NH}_{3}$ emissies in de hele mestketen. De berekeningen laten zien dat een relatieve toename van de ruweiwit in het rantsoen met $12,5 \%$ resulteert in een toename van de ammoniakemissie van $21 \%$. Wanneer meer beweiding wordt toegepast (hogere TAN in vers gras) dient het rantsoen (krachtvoer in de stal) te worden aangepast om dit te compenseren.

- $\quad$ Bij bedrijven met een automatisch melksysteem (AMS) zal de reductie per beweidingsuur lager uitvallen dan bij conventionele melksystemen omdat door continue koeverkeer er een grotere (tijd) bevuilde oppervlakte ontstaat en daardoor een grotere kans op emissie is. 


\section{$1 \quad$ Inleiding}

Beweiding is een PAS (Programmatische Aanpak Stikstof) maatregel om de ammoniakemissies uit de rundveehouderij te reduceren (PAS 2015.08.02). Een voorwaarde bij deze maatregel is dat alle melken kalfkoeien in de stal minimaal 720 uur per kalenderjaar geweid moeten worden. Aan deze maatregel wordt een ammoniakemissiereductie van 5\% toegekend. Sinds 2000 wordt weidegang steeds minder toegepast (Van Bruggen en Faqiri, 2015): werd er in 2000 slechts 5\% van de dieren in de stal gehouden, in 2013 steeg dit percentage naar 30\% van de dieren, en sindsdien is dit gestabiliseerd. De ambitie van de sector (Duurzame zuivelketen, 2015) is om het aandeel weidegang minimaal op het niveau van 2012 (81,2\% van alle bedrijven weidt) te houden. Van Bruggen en Faqiri (2015) noemen een aantal knelpunten die de trend naar minder beweiden zou kunnen hebben veroorzaakt:

- Schaalvergroting, waardoor dieren een grotere afstand moeten leggen om naar de weide en terug naar de stal (om gemolken te worden) te gaan.

- Intensivering in de melkveehouderij. Beweiding wordt voor grote bedrijven als nadelig gezien met name wat betreft het rantsoen (doel: zo constant mogelijk houden), het gebruik maken van de geproduceerde mest (doel: zo efficiënt mogelijk), en het melken van de dieren (gebruik van melkrobots in grotere mate toegepast).

Om de juiste indicatie te geven van het effect van beweiding op de $\mathrm{NH}_{3}$-emissies van een bedrijf dient rekening gehouden te worden met de gehele mestketen. Uit mest die in de wei terecht komt, ontsnapt relatief minder ammoniak $\left(\mathrm{NH}_{3}\right)$ dan in de stal. Daarnaast wordt minder mest in de stal geproduceerd, en moet minder mest worden uitgereden. De vraag is of er ook andere voor- of nadelen in de rest van de keten zijn, afhankelijk van de opslag, verwerking en toedieningsmethode. De toenemende schaalgrootte vraagt ook aandacht. Door groei van bedrijven bij een gelijkblijvende omvang van de huiskavel ontstaat minder beweidingsruimte. Bovendien blijkt uit lopend onderzoek (Van Dooren et al., 2016; in voorbereiding) dat de stal tijdens het beweiden langer door-emitteert dan tot nu toe wordt aangenomen.

Dit onderzoek beoogt de informatie van verschillende lopende initiatieven en studies naar beweiding en stallen tijdens beweiding bij elkaar te brengen, het effect van verschillende beweidings-strategieën op de ammoniakemissies over de gehele mestketen (weide, stal, opslag, toediening) te onderzoeken, en na te gaan welke aanpassingen op het bedrijf nodig zijn om dit te kunnen realiseren. In hoofdstuk

2 wordt achtergrondinformatie weergegeven over de ammoniakemissiebronnen uit de landbouw en de belangrijkste processen die de ammoniakemissie kunnen beïnvloeden. In hoofdstuk 3 wordt een overzicht gegeven van de geselecteerde beweidings-scenario's. Het effect van deze scenario's op de ammoniakemissie in de gehele mestketen wordt in hoofdstuk 4 gepresenteerd. In hoofdstuk 5 worden de belangrijkste conclusies van deze studie weergegeven. 


\section{Achtergrondinformatie}

\subsection{Ammoniakemissiebronnen}

De uitstoot en depositie van $\mathrm{NH}_{3}$ resulteert in een aantal milieuproblemen (verzuring, vermesting, vervuiling van grond- en oppervlaktewateren, afname van de biodiversiteit van de natuur). Daarnaast is depositie van $\mathrm{NH}_{3}$ verantwoordelijk voor de (indirecte) emissie van $\mathrm{N}_{2} \mathrm{O}$, en een bron van secundaire fijn stof (door omzetting in de atmosfeer; Figuur 1).

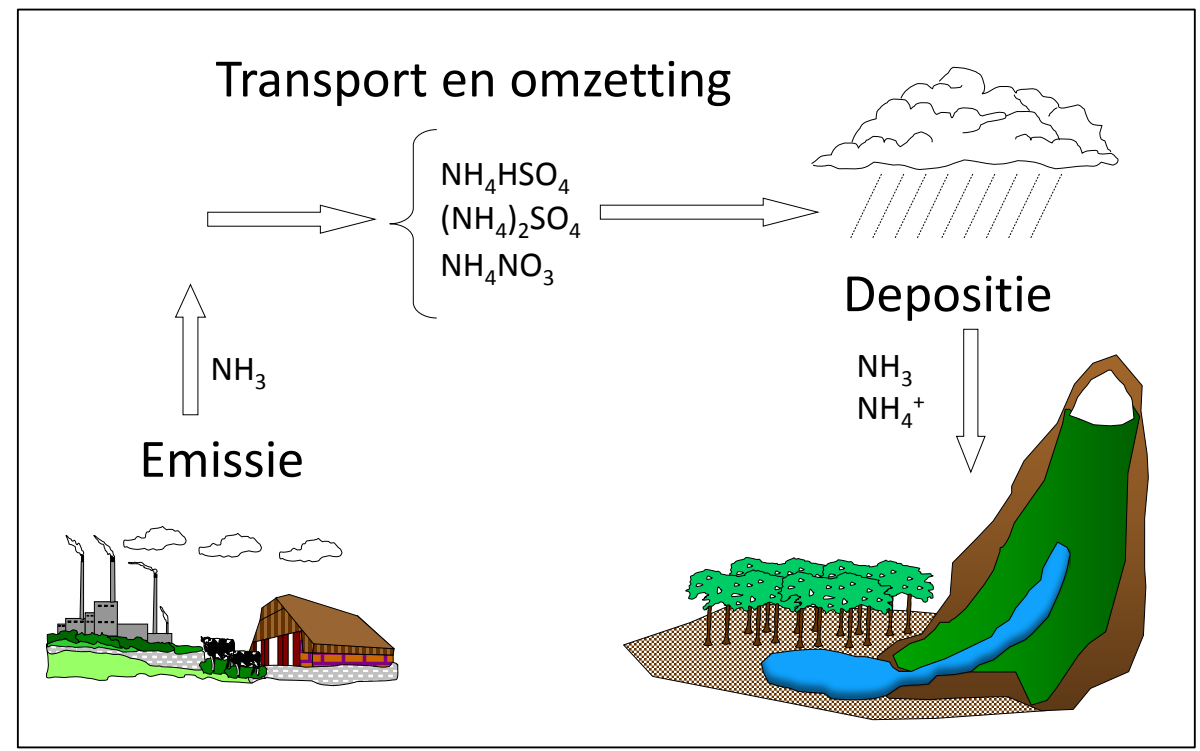

Figuur $1 \quad \mathrm{NH}_{3}$-kringloop

De landbouw is de belangrijkste bron van ammoniakemissies in Nederland. In 2013 droeg de landbouw voor $84 \%$ bij aan de nationale uitstoot van $\mathrm{NH}_{3}$ (Figuur 2). De belangrijkste landbouwbronnen zijn stallen (en mestopslag), en het aanwenden van mest, samen in 2013 verantwoordelijk voor $83 \%$ van de totale uitstoot van ammoniak uit de Nederlandse landbouw (figuur 3). Melkvee is de grootste producent, gevolgd door varkens en pluimvee (figuur 4).

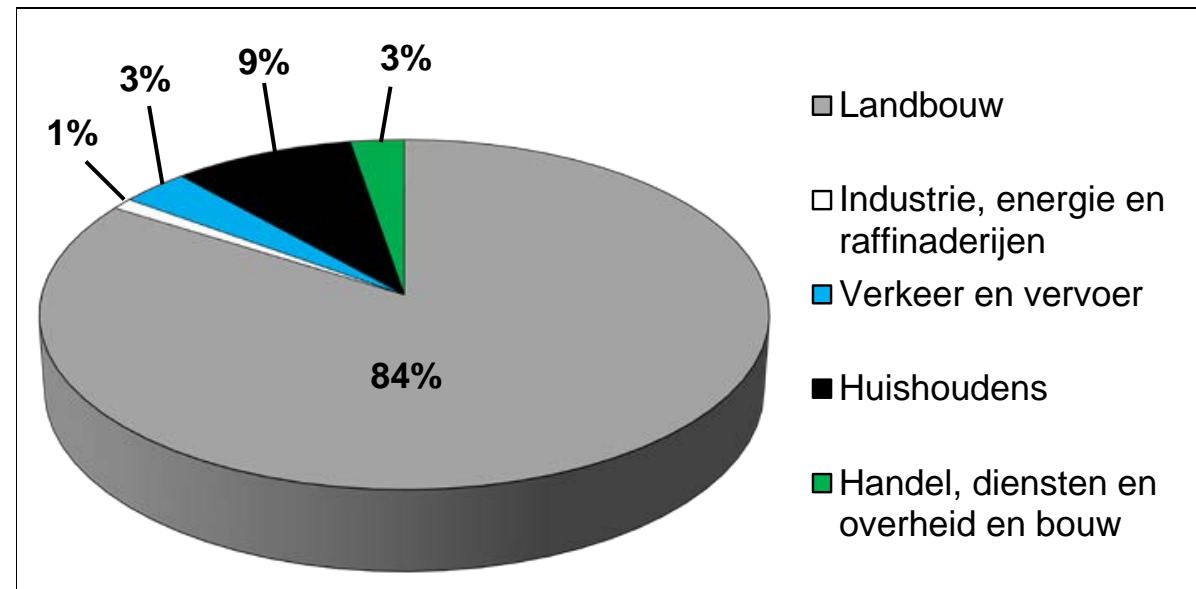

Figuur $2 \mathrm{NH}_{3}$ emissies per doelgroep. Bron: www.emissieregistratie. $\mathrm{nl}$ (2015). 


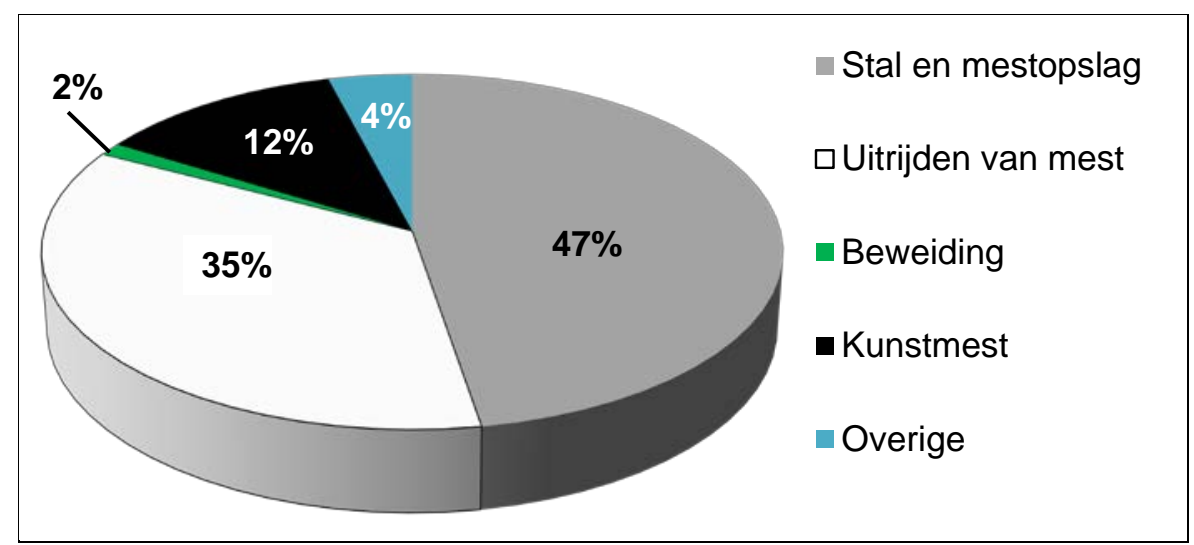

Figuur $3 \quad \mathrm{NH}_{3}$ emissies uit de Nederlandse landbouw in 2013 (per bron). Bron: www.emissieregistratie. $\mathrm{nl}$ (2015).

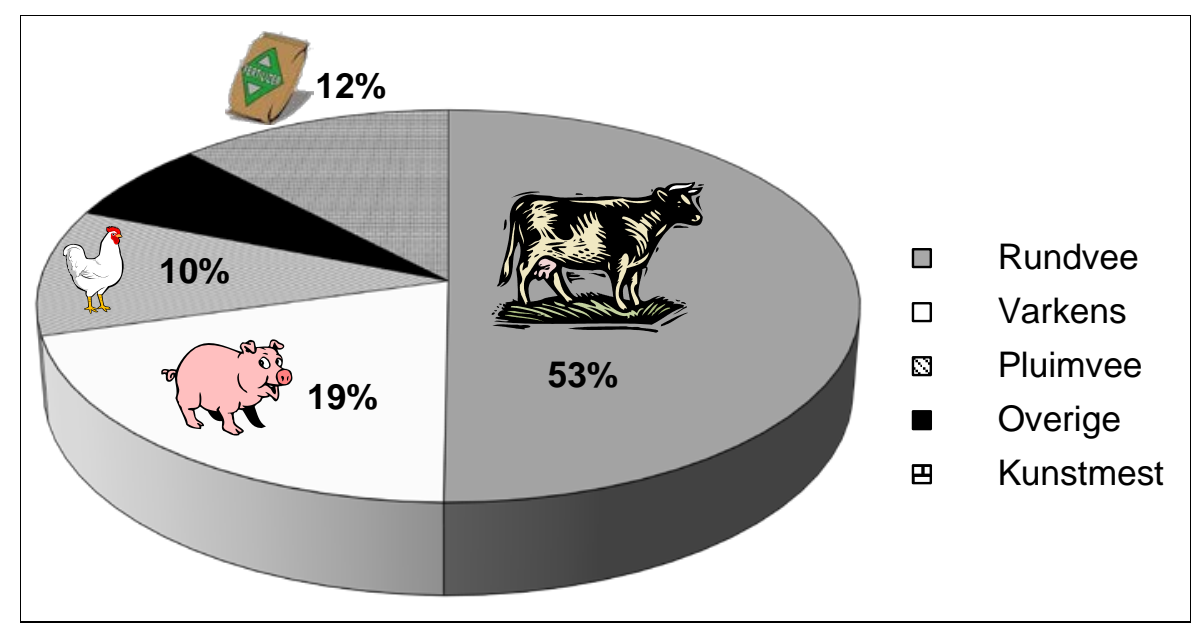

Figuur $4 \quad \mathrm{NH}_{3}$ emissies uit de Nederlandse landbouw in 2013 (per diercategorie). Bron: www.emissieregistratie.nl (2015)

Niet alleen ammoniak, maar ook geur, fijnstof en broeikasgassen, worden geproduceerd in alle onderdelen van de mestketen (Figuur 5). Het is belangrijk om ervoor te zorgen dat de reductie van de uitstoot van een bepaalde verontreinigende stof (bijv. $\mathrm{NH}_{3}$ ) op een specifiek onderdeel van de mestketen (Figuur 5), niet leidt tot een toename van de emissies ergens anders (of van een andere stof) in de mestketen. Het is daarom van belang om rekening te houden met mogelijke neveneffecten over de gehele mestketen (beweiding, stal, opslag, verwerking, toediening).

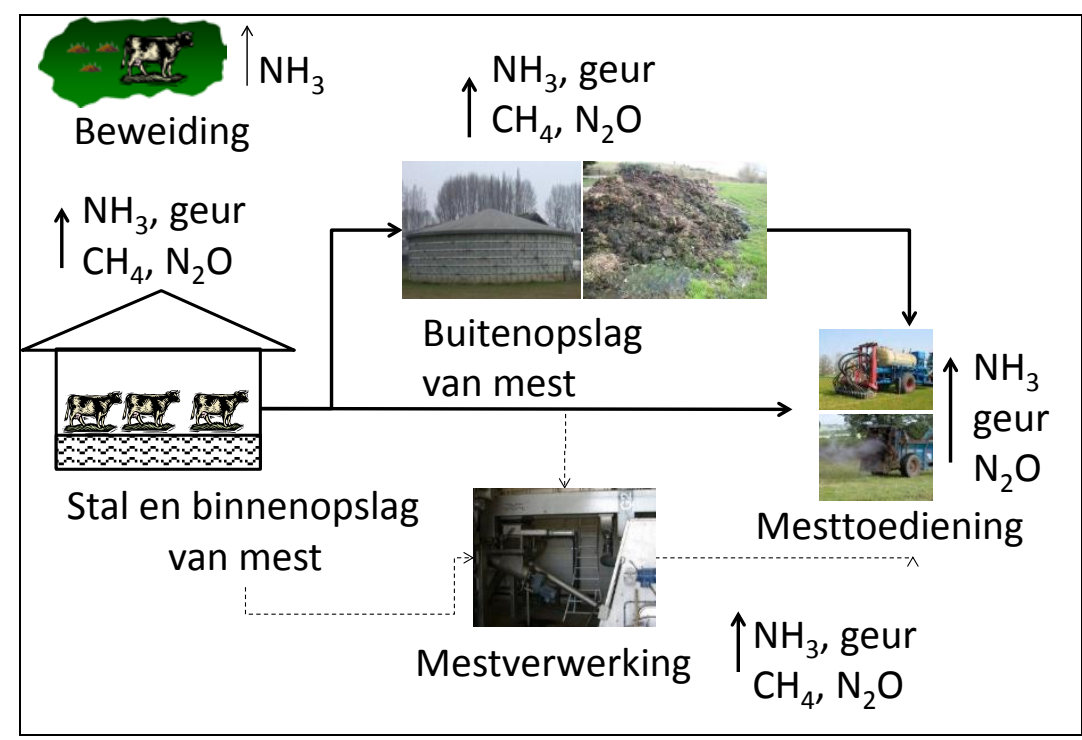

Figuur 5 Emissies in de mestketen 


\subsection{Ammoniakemissie uit de landbouw: processen en factoren}

Slechts een klein gedeelte van de door dieren geconsumeerde stikstof wordt opgenomen in het dier (Tamminga, 1992), de rest wordt uitgescheiden als de stikstofverbinding ureum in de urine, en organische gebonden stikstof in de feces (proces 1 in Figuur 6). Een deel van de feces en urine komt op de (rooster)vloer terecht, de rest valt in de mestkelder.

Ammoniak wordt geproduceerd door omzetting van ureum (urine) en organisch gebonden stikstof (feces) door het in de feces aanwezige enzym urease (proces 2 in Figuur 6). Deze hoeveelheid potentieel vluchtige $\mathrm{N}$ wordt vaak uitgedrukt als TAN (Totaal ammoniakale stikstof). Hoe meer stikstof in het voer, hoe meer niet benutte $\mathrm{N}$, hoe hoger de fractie TAN in de mest en hoe groter de kans op ammoniakvervluchtiging. De omzetting van ureum vindt snel plaats, binnen enkele uren kan de ureumvoorraad in de plassen op de vloer uitgeput zijn (Elzing and Monteny, 1997a,b). Ammonium in de urine is in evenwicht met ammoniak (opgelost in de urine; proces 3 in Figuur 6). De opgeloste ammoniak is op zijn beurt in evenwicht met ammoniak in de onderste luchtlaag (in contact met de mest/urinemengsel), die door diffusie kan vervluchtigen (proces 4 in Figuur 6). Dit proces is afhankelijk van het verschil in concentratie tussen ammoniak in de mest/urinemengsel en in de onderste luchtlaag.

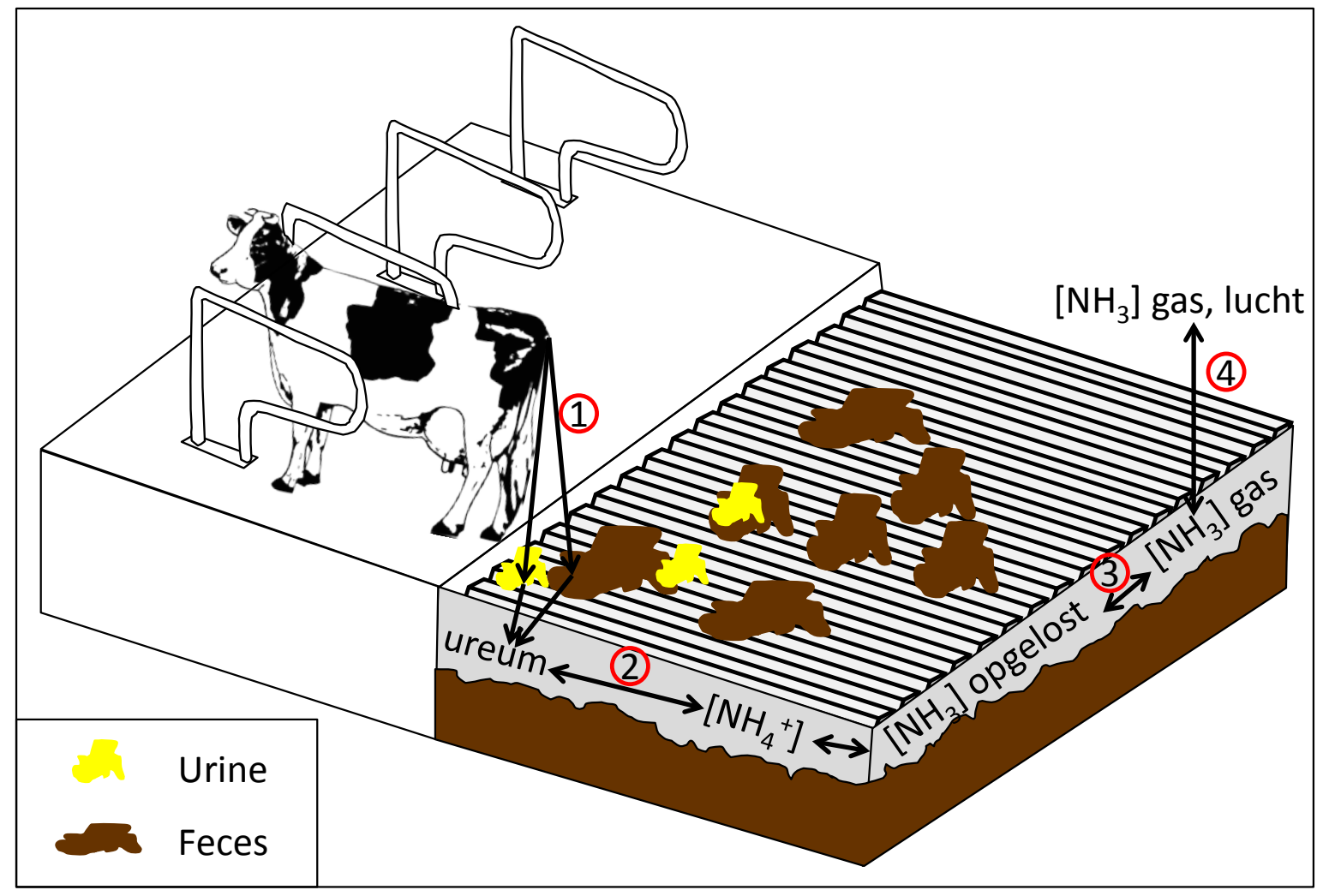

Figuur 6 Ammoniakemissie uit stallen (aangepast van Monteny et al., 1998)

Er zijn verschillende factoren die de emissie van ammoniak kunnen beïnvloeden. Deze worden in Tabel 1 samengevat. 
Tabel 1 Sleutelfactoren die de emissie van $\mathrm{NH}_{3}$ uit stal, opslag en toediening kunnen beïnvloeden (tabel op basis van informatie uit Groenestein et al., 2010).

+: toename van emissie; -: afname van emissie; 0: geen relevant effect wanneer de sleutelfactor toeneemt; *: effect afhankelijk van de aanwezigheid of soort sleutelfactor. Een cijfer in de kolom voor $\mathrm{pH}$ duidt op een optimale $\mathrm{pH}$.

\section{$\mathrm{NH}_{3}$}

\section{Dierfactoren}

Diercategorie en massa van de dieren

Hoeveelheid en samenstelling voer

Watergebruik

\section{Mesteigenschappen}

Mestsamenstelling

$\mathrm{NH}_{4}{ }^{+}$-concentratie (TAN, Total Ammonium Nitrogen) +

$\mathrm{pH}$

Organische stof concentratie

Drogestofgehalte

$0 /+$

$\mathrm{C} / \mathrm{N}$-ratio

$\mathrm{O}_{2}$-concentratie

Mestoppervlakte

Leeftijd mest / Opslagtijd

Mesttemperatuur

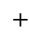

$+$

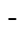

\section{Omgevingsfactoren}

Stal, opslag en toediening

Lucht-/windsnelheid

Temperatuur binnenlucht

Temperatuur buitenlucht

Toediening

Zonnestraling

Regenval

Luchtvochtigheid

\section{Gewas en bodemeigenschappen}

Gewas

Grondsoort en -structuur

Infiltratiesnelheid

$-$

Bodemvochtgehalte

$0 /+$

Wanneer weidegang wordt toegepast, zijn de dieren voor een deel van de tijd in de stal, en voor een deel van de tijd in de weide. Beide bronnen moeten meegenomen worden in de berekening van de emissies voor de verschillende beweidingsscenario's. De volgende factoren zijn van belang in relatie tot ammoniakemissie bij beweiding:

a) Beweidingsuren.

- $\quad$ Hoe meer dieren (in de stal of in de weide) per beschikbare oppervlakte, hoe hoger de kans dat mest en urine in contact komen, met een hogere risico voor ammoniakemissies als gevolg. De kans dat mest en urine in contact komen is in de weide veel lager dan in de stal. Door meer weidegang toe te passen, zal de gecombineerde (stal + weide) ammoniakemissie daardoor afnemen.

- $\quad$ Naar mate dieren meer uren in de weide zijn, zal meer mest in de weide worden geproduceerd, en minder in de stal. Aangezien de emissie uit mest in de weide ( $4 \%$ van de uitgescheiden TAN oftewel Total Ammonium Nitrogen) veel lager is dan uit mest in de stal $(13,4 \%$ van de uitgescheiden TAN voor overige huisvestingssystemen voor melkvee), zal de gecombineerde emissie (stal + weide) met meer beweiding in het algemeen lager zijn dan wanneer de dieren vaker in de stal zijn. 
- Uitdoving (van de ammoniakemissie) in de stal speelt ook een belangrijke rol. Wanneer de dieren uit de stal zijn, zal de nog aanwezige mest in de stal ammoniak blijven emitteren. Deze emissie zal in de loop van de tijd afnemen (uitdoving). Momenteel wordt aangenomen op basis van eerdere meetreeksen dat (voor een traditionele stal met roostervloer) voor elk uur in de weide, de ammoniakemissie uit de stal met 2,61\% omlaag gaat (Ogink et al., 2014).

- Mest die in de stal is geproduceerd zal moeten worden opgeslagen (binnen of buiten de stal) en daarna toegediend aan grasland of bouwland, met meer ammoniakemissies als gevolg.

b) Rantsoen.

Afhankelijk van het rantsoen, en vooral het gemiddelde ruw eiwitgehalte en de verteerbaarheid van dat eiwit, zal de TAN in de mest en urine variëren. Door meer weidegang toe te passen bestaat het risico dat de dieren met meer vers weidegras een hoger eiwitgehalte in het rantsoen krijgen, waardoor de TAN in mest en urine hoger zal zijn. Wanneer meer beweiding wordt toegepast (hogere TAN in vers gras) dient het rantsoen te worden aangepast om dit te compenseren. 


\section{Scenario's voor weidegang en berekeningsmethodiek}

Op basis van de in het vorige hoofdstuk benoemde parameters is een aantal beweidingsscenario's gekozen. Deze scenario's zijn in Tabel 2 samengevat. Bij de verschillende scenario's is rekening gehouden met:

- Aantal uren in de weide, variërend van weinig beweiding (360 uren) tot veel beweiding (4800 uren).

- Veebezetting, afhankelijk van de scenario's variërend tussen 2 en 10 dieren per ha beweidbare oppervlakte.

- Ruweiwitgehalte van het rantsoen. Om het effect van rantsoen op de ammoniakemissie in te schatten is het ruweiwit van het rantsoen bij scenario 10 verhoogd (van 160 naar $180 \mathrm{~g} / \mathrm{kg}$ drogestof) en bij scenario 11 verlaagd (van 160 naar $140 \mathrm{~g} / \mathrm{kg}$ drogestof).

- Melksysteem: conventionele melksystemen (scenario's $1 \mathrm{t} / \mathrm{m}$ 6, 10 en 11) versus een automatisch melksysteem (AMS). Bij AMS varianten (scenario's $7 \mathrm{t} / \mathrm{m}$ 9) lopen koeien in en uit om binnen gemolken te kunnen worden en buiten vers gras op te nemen. Globaal hebben de dieren daardoor 1,5 keer zoveel toegangstijd nodig voor weidegang dan bij conventionele melksystemen (Van den Pol-van Dasselaar et al., 2015). Om rekening te houden met dit effect is het aantal dieren dat op stal is tijdens de beweidingsuren voor de scenario's met AMS verhoogd (aanname: $25 \%$ van de dieren continue op stal tijdens beweiding met AMSsysteem).

Om het effect van de verschillende scenario's op de emissies van ammoniak te bepalen is gebruik gemaakt van het rekenmodel NEMA (National Emission Model for Agriculture; zie Vonk et al. (2016) en Van Bruggen et al. (2015)). De uitgangspunten voor deze berekeningen zijn:

- Bedrijfsopzet.

o Een bedrijf met 120 melkkoeien.

o Gemiddelde melkproductie van $28 \mathrm{~kg}$ melk per dag (8500 kg melk op jaarbasis).

- Rantsoen.

o De dieren krijgen $3 \mathrm{~kg}$ drogestof snijmaïs en $12 \mathrm{~kg}$ drogestof voordroogkuil als basisrantsoen in de winter.

- In de zomer krijgen de dieren voordroogkuil (afhankelijk van beweidings-scenario) en snijmaïs ( $3 \mathrm{~kg}$ drogestof voor scenario's met een dierbezetting van meer dan 2 dieren per huiskavel; $1 \mathrm{~kg}$ drogestof voor de scenario met 2 dieren per huiskavel) als bijvoeding.

o Gemiddeld ruweiwit op totaal rantsoen in de zomer en de winter vastgesteld op 160 $\mathrm{g} / \mathrm{kg}$ drogestof. 
Tabel 2 Scenario's voor beweiding. vdk: voordroogkuil; rantsoen in kg drogestof. AMS = automatisch melksysteem

\begin{tabular}{|c|c|c|c|c|c|c|c|c|}
\hline $\begin{array}{l}\text { Onderzocht } \\
\text { effect }\end{array}$ & Scenario & $\begin{array}{l}\text { Veebezetting } \\
\text { (dieren per ha) }\end{array}$ & $\begin{array}{l}\text { Totaal } \\
\text { uren } \\
\text { in de stal }\end{array}$ & $\begin{array}{c}\text { Totaal uren } \\
\text { in de wei }\end{array}$ & $\begin{array}{l}\text { Eiwit in } \\
\text { rantsoen } \\
\text { (g/kg ds) }\end{array}$ & $\begin{array}{l}\text { Vers } \\
\text { gras in } \\
\text { zomer } \\
\text { (kg ds) }\end{array}$ & $\begin{array}{l}\text { Aanvullend } \\
\text { basis rantsoen } \\
\text { (zomer) (kg ds) }\end{array}$ & $\begin{array}{l}\text { Basis } \\
\text { rantsoen } \\
\text { winter } \\
\text { (kg ds) }\end{array}$ \\
\hline \multirow[t]{4}{*}{ Beweidingsuren } & 1 & 2 & 3960 & 4800 & 160 & 15 & - & 12 vdk 3 maiis \\
\hline & 2 & 2 & 5160 & 3600 & 160 & 14 & 1 maïs & $12 \mathrm{vdk} 3$ maïs \\
\hline & 3 & 4 & 7230 & 1530 & 160 & 8,3 & 3,7 vdk 3 maïs & 12 vdk 3 maïs \\
\hline & 6 & 10 & 8400 & 360 & 160 & 2,5 & 9,5 vdk 3 maïs & $12 \mathrm{vdk} 3$ maïs \\
\hline \multirow[t]{3}{*}{ Melksysteem } & 7 & 2 AMS & 5610 & 3150 & 160 & 14 & 1 maïs & $12 \mathrm{vdk} 3$ maïs \\
\hline & 8 & 4 AMS & 7039 & 1721 & 160 & 8,3 & 3,7 vdk 3 maïs & 12 vdk 3 maïs \\
\hline & 9 & $8 \mathrm{AMS}$ & 8274 & 486 & 160 & 3,6 & 8,4 vdk 3 maïs & $12 \mathrm{vdk} 3$ maïs \\
\hline Rantsoen-eiwit & 10 & 2 & 5160 & 3600 & 180 & 14 & 1 maïs & 12 vdk 3 maïs \\
\hline
\end{tabular}


Met de gegevens in tabel 2 zijn voor elk van de gekozen varianten stikstof-excretiefactoren berekend. Hiervoor is de WUM-berekening van 2014 als uitgangspunt genomen (Van Bruggen et al., 2016; in voorbereiding). Voor elk van de varianten zijn in de WUM-berekening van 2014 de hoeveelheden ruwvoer in het rantsoen gebaseerd op de uitgangspunten in tabel 2. De hoeveelheid krachtvoer is vervolgens zodanig aangepast dat de VEM-opname in overeenstemming is met de VEM-behoefte. De implementatiegraden van beweidingssystemen (dag en nacht weiden, overdag weiden en permanent opstallen) zijn zo aangepast dat het aantal uren in de wei overeenstemt met het aantal weide-uren. Het uitgangspunt is een weideperiode van 180 dagen. Voor extreme vormen van beweiding is hier van afgeweken. Per beweidingssysteem is het aantal uur per etmaal in de wei afgestemd met WUM: bij dag en nacht weiden is het aantal weide-uren globaal $85 \%$ (20 uur) en bij overdag weiden is dit $67 \%$ ( 8 uur) met uitzondering van variant 1 waarbij de koeien dag en nacht ( 24 uur) in de wei staan. Ter vergelijking zijn twee scenario's (5 en 6 ) met minder beweidingsuren toegevoegd. In deze scenario's is het aantal beweidingsuren minder dan het minimum aantal uren dat koeien volgens leaflet PAS 2015.08.02 moeten weiden om het kenmerk beweiding te krijgen ( 120 dagen per jaar, 6 uren per dag: 720 beweidingsuren). In tabel 3 staat een overzicht van de uitgangspunten.

Tabel 3 Uitgangspunten emissieberekeningen.

\begin{tabular}{|c|c|c|c|c|c|c|c|c|c|}
\hline & & \multicolumn{8}{|c|}{ Varianten } \\
\hline & & 1 & 2,10 & 3 & 4,11 & 5,9 & 6 & 7 & 8 \\
\hline Weideperiode & dagen & 200 & 180 & 180 & 123,7 & 60 & 45 & 180 & 180 \\
\hline Onbeperkt weiden & $\%$ dagen & 100 & 96,8 & 4,1 & 0,0 & 0,0 & 0,0 & 76,6 & 12,6 \\
\hline Beperkt weiden & $\%$ dagen & 0,0 & 3,2 & 96,0 & 100,0 & 100,0 & 100,0 & 23,4 & 87,4 \\
\hline Permanent op stal & $\%$ & 0,0 & 0,0 & 0,0 & 0,0 & 0,0 & 0,0 & 0,0 & 0,0 \\
\hline Weide-uren & $\%$ etmaal & 100,0 & 83,3 & 35,4 & 33,3 & 33,3 & 33,3 & 72,9 & 39,8 \\
\hline Weide-uren & uren & 4800 & 3600 & 1530 & 990 & 480 & 360 & 3150 & 1721 \\
\hline Melkproductie & $\mathrm{kg}$ & 8500 & 8500 & 8500 & 8500 & 8500 & 8500 & 8500 & 8500 \\
\hline Stalperiode Vochtrijk KRV & $\mathrm{kg} \mathrm{ds} / \mathrm{d}$ & 0,9 & 0,9 & 0,9 & 0,9 & 0,9 & 0,9 & 0,9 & 0,9 \\
\hline Stalperiode Eiwitrijk KRV & $\mathrm{kg} / \mathrm{d}$ & 1,3 & 1,3 & 1,3 & 1,3 & 1,3 & 1,3 & 1,3 & 1,3 \\
\hline Stalperiode Eiwitarm KRV & $\mathrm{kg} / \mathrm{d}$ & 3,2 & 3,2 & 3,2 & 3,2 & 3,2 & 3,2 & 3,2 & 3,2 \\
\hline Stalperiode Snijmaïs & $\mathrm{kg} \mathrm{ds} / \mathrm{d}$ & 3,0 & 3,0 & 3,0 & 3,0 & 3,0 & 3,0 & 3,0 & 3,0 \\
\hline Stalperiode Graskuil & $\mathrm{kg} \mathrm{ds} / \mathrm{d}$ & 12,0 & 12,0 & 12,0 & 12,0 & 12,0 & 12,0 & 12,0 & 12,0 \\
\hline Weideperiode Vochtrijk KRV & $\mathrm{kg} \mathrm{ds} / \mathrm{d}$ & 0,6 & 0,6 & 0,6 & 0,6 & 0,6 & 0,6 & 0,6 & 0,6 \\
\hline Weideperiode Eiwitarm KRV & $\mathrm{kg} / \mathrm{d}$ & 4,3 & 4,3 & 4,5 & 4,8 & 5,0 & 5,1 & 4,3 & 4,5 \\
\hline Weideperiode Snijmaïs & $\mathrm{kg} \mathrm{ds} / \mathrm{d}$ & 0 & 1,0 & 3,0 & 3,0 & 3,0 & 3,0 & 1,0 & 3,0 \\
\hline Weideperiode Graskuil & $\mathrm{kg} \mathrm{ds} / \mathrm{d}$ & 0 & 0,0 & 3,7 & 6,8 & 8,4 & 9,5 & 0,0 & 3,7 \\
\hline Weideperiode Vers gras & $\mathrm{kg} \mathrm{ds} / \mathrm{d}$ & 15,0 & 14,0 & 8,3 & 5,2 & 3,6 & 2,5 & 14,0 & 8,3 \\
\hline
\end{tabular}

Verder zijn de stikstofgehalten van de voedermiddelen zodanig aangepast dat het rantsoen voor de varianten 1 tot en met $9 \mathrm{ca} .160 \mathrm{~g}$ eiwit per $\mathrm{kg}$ droge stof (ds) bevat, voor variant $10180 \mathrm{~g}$ eiwit/ kg ds en voor variant $11140 \mathrm{~g}$ eiwit/ $\mathrm{kg}$ ds. Deze aanpassing is in de meeste gevallen toegepast op het krachtvoer en in een enkel geval ook op ruwvoer. De uitgangspunten van tabel 3 zijn doorgerekend met WUM voor de bepaling van de $\mathrm{N}$-excretiefactoren ( $\mathrm{N}$-totaal en TAN) en vervolgens is met het rekenmodel NEMA de ammoniakemissie berekend. Hierbij zijn alle andere uitgangspunten (Van Bruggen et al., 2016; in voorbereiding) ongewijzigd zoals:

- $\quad$ Excretiefactoren voor fosfaat;

Omvang veestapel;

VC-RE van voedermiddelen;

I mplementatiegraden van stalsystemen;

Afzet buiten de landbouw;

I mplementatiegraden van mesttoedieningstechnieken;

Verdeling van opgeslagen mest over bouwland en grasland;

Gebruik van kunstmest;

Afzet van weidemest op natuurterrein. 


\section{$4 \quad$ Resultaten en discussie}

\subsection{Beweidingsuren en uitdoving in de stal}

In Figuur 7 wordt het effect van meer beweidingsuren (door meer dagen per jaar en/of meer uren per dag) op de ammoniakemissies van melk- en kalfkoeien weergegeven. Als uitgangspunt wordt een uitdovingspercentage in de stal van 2,61\% (Ogink et al., 2014) gebruikt. In Bijlage 1 wordt een compleet overzicht gegeven van de resultaten van de berekeningen voor alle varianten (en verschillende uitdovingspercentages). Doordat uit mest in de weide minder ammoniak wordt geproduceerd dan in de stal, resulteert een toename in beweidingsuren in een reductie van de totale ammoniakemissie in de mestketen (weide, stal, opslag, toediening).

Het aantal beweidingsuren heeft een duidelijk effect op de ammoniakemissies over de hele mestketen. Het aantal uren weidegang moet wel in balans zijn met de droge stof opname van vers gras en daarmee met de beschikbare beweidingsruimte op het bedrijf. Meer weidegang vraagt een lagere veebezetting per ha, waardoor op intensievere bedrijven meer beweidbare oppervlakte nodig is om de ammoniakreductie te kunnen realiseren.

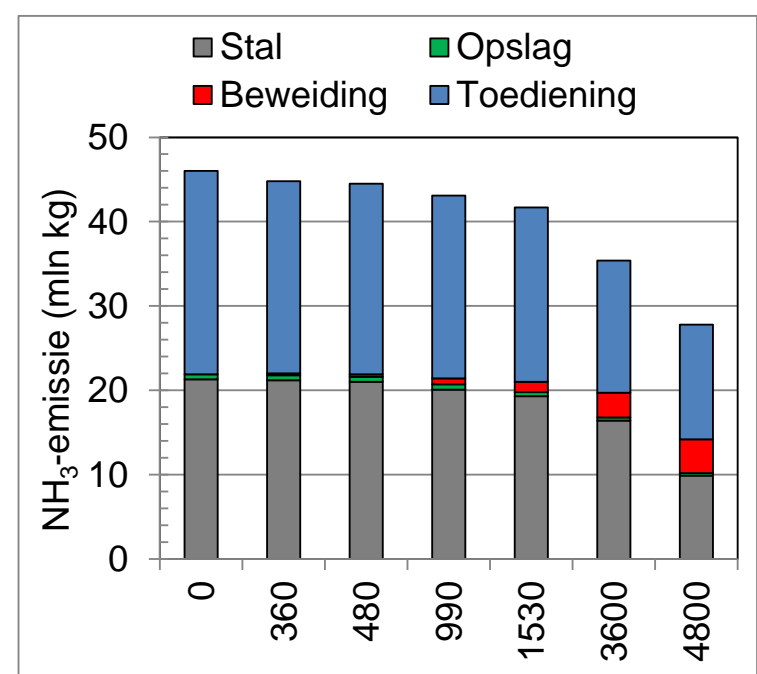

Uren in de weide

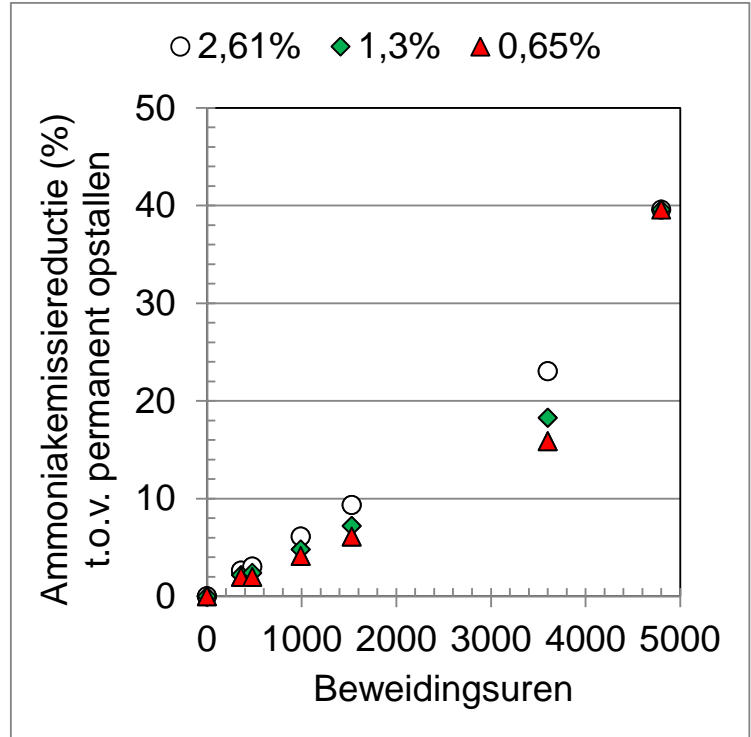

Figuur 7 Links: effect van aantal beweidingsuren op de nationale ammoniakemissie ( $\mathrm{mln} \mathrm{kg} \mathrm{per}$ jaar) voor de verschillende onderdelen in de mestketen. Rechts: effect van beweidingsuren en mate van uitdoving in de stal $(2,61 \% ; 1,3 \% ; 0,65 \%$ per uur) op de ammoniakemissie voor de gehele mestketen.

Voor weidegang wordt een vaste reductiepercentage van de ammoniakemissies uit de stal van $2,61 \%$ per beweidingsuur aangehouden. In 2015 zijn door Wageningen UR Livestock Research metingen uitgevoerd om voor de stalemissie het uitdovingseffect (hoe lang de stal blijft emitteren nadat de dieren naar de weide zijn gegaan) van beweiding te kwantificeren. De eerste berekeningen uit dit onderzoek geven aan dat het reductiepercentage dat momenteel aangenomen wordt $(2,61 \%$ per beweidingsuur; Ogink et al., 2014) een overschatting zou kunnen zijn van de werkelijke situatie. Dit zou betekenen dat het effect van beweiding overschat wordt. Om een indruk te krijgen van deze mogelijke overschatting zijn de verschillende scenario's doorgerekend met een emissiereductie per beweidingsuur die helft of een kwart van de oorspronkelijke waarde bedraagt. De resultaten worden in Figuur 7 (rechts) grafisch weergegeven. Aangezien voor de variant met 4800 beweidingsuren de dieren 24 uur per dag in de weide zijn, speelt het uitdovingspercentage geen rol meer, wat verklaart dat voor deze variant de berekeningen met verschillende uitdovingspercentages samen vallen. 
Op basis van een regressieanalyse is het effect van het aantal beweidingsuren op de emissiereductie voor deze drie verschillende varianten in uitdovingspercentage geschat op:

\begin{tabular}{cc}
\hline Uitdoving in de stal & Effect van beweiding (EB; \% t.o.v. permanent opstallen) \\
\hline $2,61 \%$ & $\mathrm{~EB}=0,0064^{*}$ beweidingsuren \\
$1,3 \%$ & $\mathrm{~EB}=0,0050^{*}$ beweidingsuren \\
$0,65 \%$ & $\mathrm{~EB}=0,0043^{*}$ beweidingsuren \\
\hline
\end{tabular}

De effecten van beweiding in de stal zijn gebaseerd op berekeningen voor een traditioneel huisvestingssysteem met roostervloer. Voor emissiearme-vloeren (meestal dichte vloeren zijn) is het effect van beweidingsuren op de ammoniakemissie 30-40\% groter dan bij roostervloeren (Ogink et al., 2014). Als voorbeeld: de ammoniakemissiereductie voor 720 beweidingsuren is geschat op $5 \%$ bij traditionele roostervloeren, en op $7 \%$ voor emissiearme-vloeren.

\subsection{Rantsoen (ruweiwit)}

Aanpassingen in het rantsoen kunnen ook een effect hebben op de ammoniakemissie (met name door het effect van die aanpassingen op de TAN-gehalte van de geproduceerde mest). Wanneer meer gebruik wordt gemaakt van weidegang, zal het TAN-gehalte van het rantsoen toenemen (meer vers gras met hoger ruweiwit in het rantsoen). Figuur 8 laat zien dat het verlagen van de ruweiwit van het rantsoen met 12,5\% (scenario met 990 beweidingsuren, ruweiwitgehalte verlaagd van 160 naar 140 $\mathrm{g} / \mathrm{kg} \mathrm{ds}$ ) tot een $19 \%$-reductie in de ammoniakemissie leidt. Een toename van de ruweiwit van het rantsoen (scenario met 3600 beweidingsuren, ruweiwitgehalte verhoogd van 160 naar $180 \mathrm{~g} / \mathrm{kg} \mathrm{ds}$ ) leidt tot een toename van de ammoniakemissies (met 21\%). De effecten van een eiwitrijk rantsoen tijdens beweiden met veel TAN-excretie worden in het gebruikte NEMA-model zowel doorberekend naar de weide-, stal- als toedieningsemissie bij het uitrijden van mest. De verdeling van TAN-excretie tussen weide en stal (en daarmee de TAN-excretie die in de stalmest terechtkomt) is in het model een functie van het aantal weide-uren. Meer beweiden leidt dus tot minder toedieningsemissie omdat een kleiner deel van de TAN-excretie wordt uitgereden. Maar een eiwitrijker rantsoen compenseert dit weer zoals Figuur 8 laat zien. Om een deel van de winst (reductie in ammoniakemissies) door beweiding niet te verliezen door een hoger ruweiwit dient daarom het rantsoen goed gebalanceerd te worden.

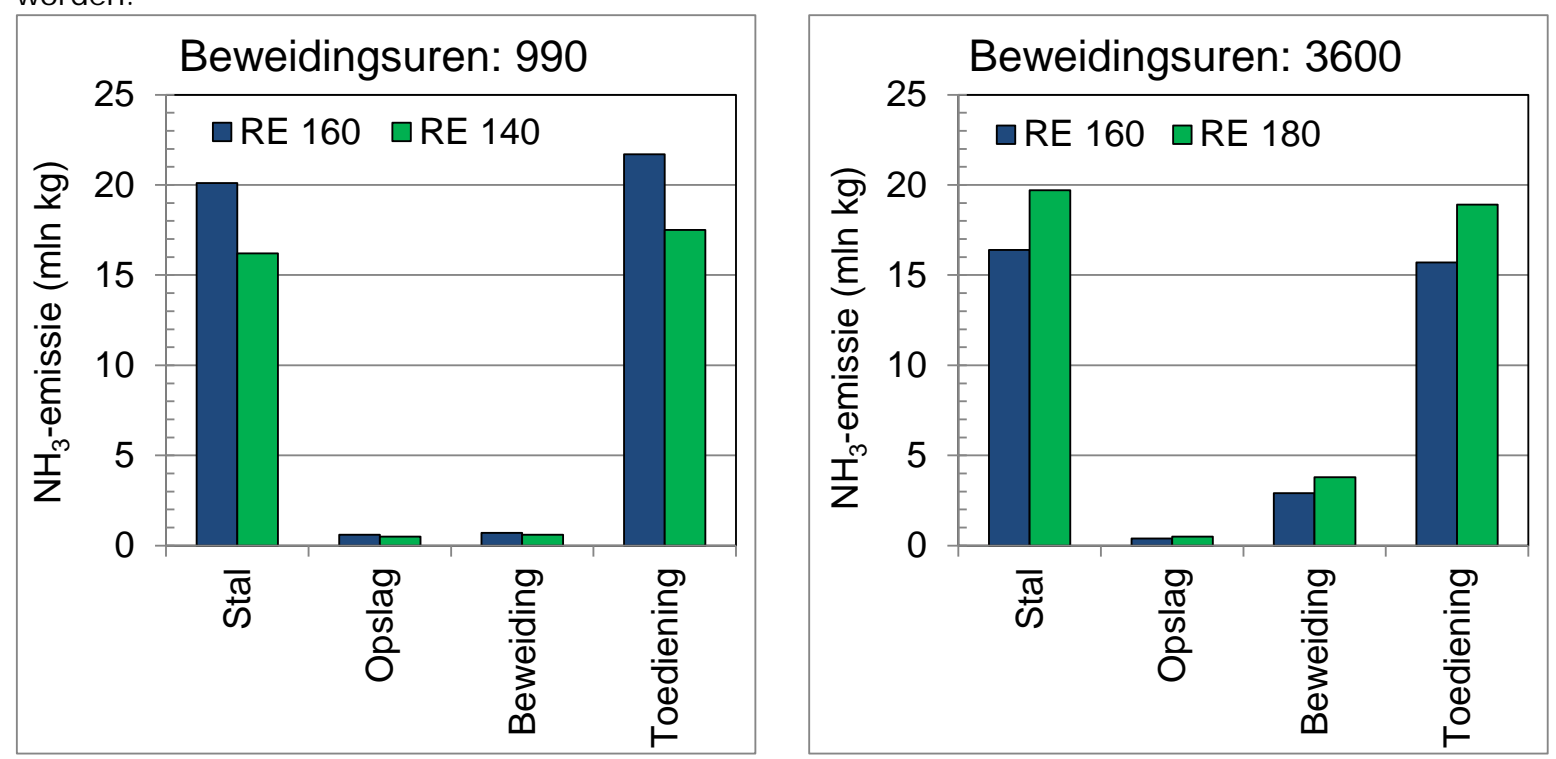

Figuur 8 Effect van aanpassingen in het rantsoen (ruweiwit) op de ammoniakemissie in de mestketen. Links: scenario met weinig weidegang (990 uren); Rechts: scenario met veel weidegang (3600 uren). Uitdovingspercentage: $2,61 \%$. 


\subsection{Automatisch melksysteem}

Bij een automatisch melksysteem kunnen de dieren in en uit de stal lopen om vrijwillig gemolken te worden of te gaan weiden. Dit betekent niet alleen dat dieren meer beweidingsuren nodig hebben om dezelfde grasopname te bereiken, maar ook dat ze een deel van die tijd rond het melken toch in de stal zullen blijven. Dit kan resulteren in een hogere ammoniakemissie uit de stal. Dit effect zal met name een grotere invloed hebben in situaties met veel beweiding en een lagere veebezetting per ha beweidbare oppervlakte (Figuur 9 links; scenario 2 met conventioneel melksysteem, versus scenario 7 met AMS). Bij beperkt beweiding (figuur 9 rechts) is het effect van melksysteem op de ammoniakemissie niet te onderscheiden tussen conventionele melksystemen en AMS. De dieren blijven langer in de stal, waardoor de extra tijd die dieren in de stal blijven met AMS t.o.v. een conventioneel melksysteem beperkt blijft.
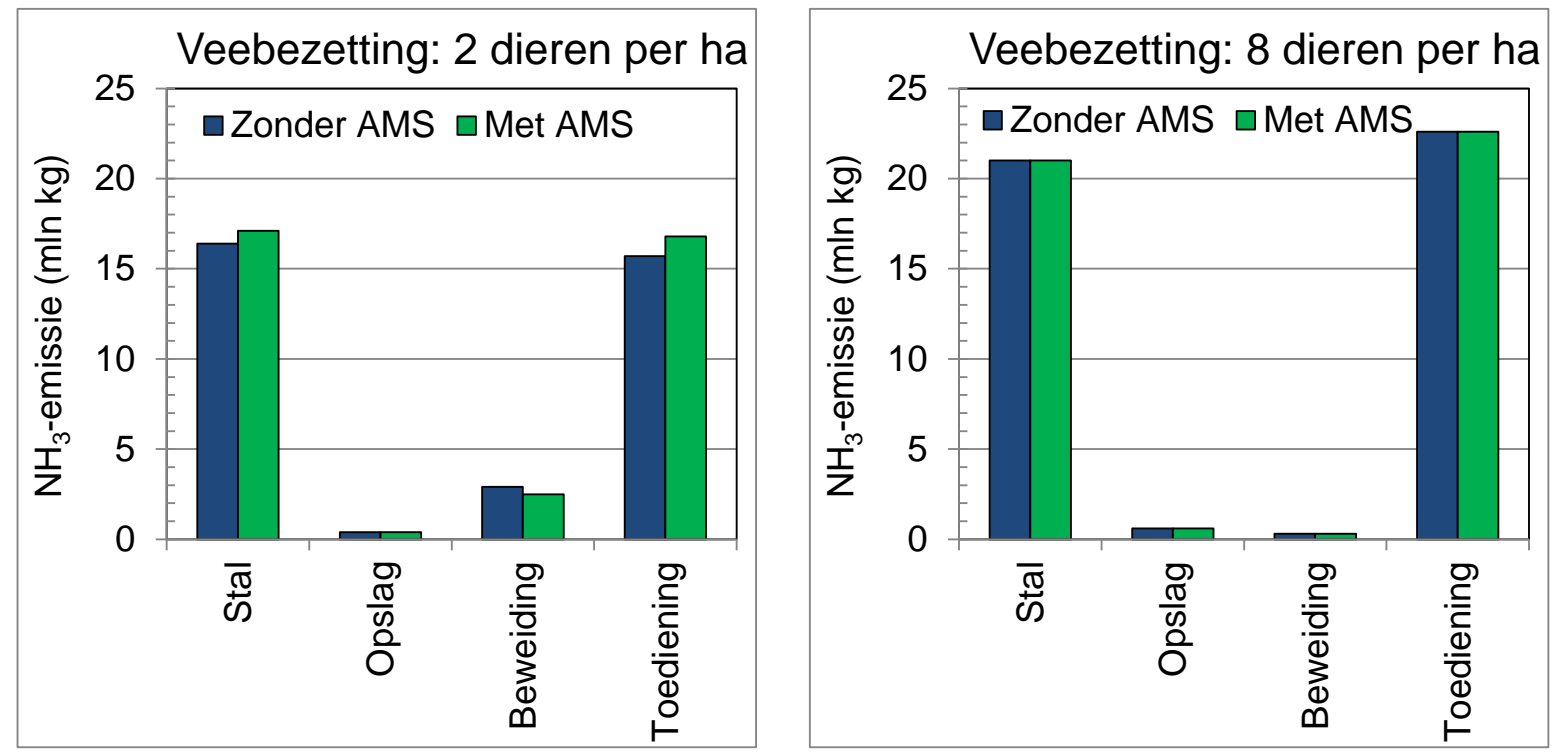

Figuur 9 Effect van melksysteem (automatisch (AMS) versus conventioneel) op de ammoniakemissie in de mestketen. Links: scenario met veel weidegang en lage veebezetting per beweidbare oppervlakte; Rechts: scenario met weinig weidegang. 


\section{Conclusies}

Op basis van de berekeningen gerapporteerd in deze deskstudie kunnen de volgende conclusie worden getrokken:

- Het aantal beweidingsuren heeft een duidelijk effect op de ammoniakemissies over de hele mestketen. Het aantal uren weidegang moet wel in balans zijn met de droge stof opname van vers gras en daarmee met de beschikbare beweidingsruimte op het bedrijf. Meer weidegang vraagt een lagere veebezetting per ha, waardoor op intensievere bedrijven meer beweidbare oppervlakte nodig is om de ammoniakreductie te kunnen realiseren.

- De omvang en de duur van het uitdovingseffect op de ammoniakemissie uit de stal als gevolg van het verblijf van dieren in de weide speelt een belangrijke rol bij realiseerbare emissiereductie. Hoe hoger het uitdovingspercentage, hoe hoger de reductie die door beweiding bereikt kan worden.

- De effecten van beweiding in de stal zijn gebaseerd op berekeningen voor een traditioneel huisvestingssysteem met roostervloer. Voor emissiearme-vloeren (die voornamelijk dichte vloeren zijn) is het effect van beweidingsuren op de ammoniakemissie 30-40\% groter dan bij roostervloeren.

- Aanpassingen in het rantsoen (ruweiwit) hebben een direct effect op de ammoniakemissie in de mestketen. Wanneer door aanpassingen in het rantsoen de ruweiwit in het rantsoen toeneemt, zal de TAN in de mest toenemen, en daardoor ook de $\mathrm{NH}_{3}$-emissies in de hele mestketen. De berekeningen laten zien dat een toename van de ruweiwit in het rantsoen met $12,5 \%$ resulteert in een toename van de ammoniakemissie (over de hele mestketen) van $21 \%$. Wanneer meer beweiding wordt toegepast (hogere TAN in vers gras) dient het rantsoen (krachtvoer in de stal) te worden aangepast om dit te compenseren.

- $\quad$ Bij bedrijven met een automatisch melksysteem (AMS) zal de reductie per beweidingsuur lager uitvallen dan bij conventionele melksystemen omdat door continue koeverkeer er een grotere (tijd) bevuilde oppervlakte ontstaat en daardoor een grotere kans op emissie is. 


\section{Literatuur}

Elzing, A., en G.J. Monteny. 1997. Ammonia emission in a scale model of a dairy-cow house. Transactions of the ASAE 40: 713-720.

Elzing, A., en G.J. Monteny. 1997b. Modeling and experimental determination of ammonia emission rates from a scale model dairy-cow house. Transactions of the ASAE 40, 721-726.

Groenestein, C.M., J.F.M. Huijsmans, en R.L.M. Schils. 2010. Emissies van broeikasgassen, ammoniak, fijn stof en geur in de mestketen. Wageningen UR Livestock Research Rapport 248.

Monteny, G.J., D.D. Schulte, A. Elzing, en E.J.J . Lamaker. 1998. A conceptual mechanistic model for the ammonia emissions from free stall cubicle dairy cow houses. Transactions of the ASAE 41(1), 193-201.

Ogink, N.W.M., C.M. Groenestein, en J. Mosquera. 2014. Actualiseren ammoniakemissiefactoren rundvee: advies voor aanpassing in de Regeling ammoniak en veehouderij. Wageningen UR Livestock Research Rapport 744.

Tamminga, S. 1992. Nutrition management of dairy cows as a contribution to pollution control. Journal of Dairy Science 75, 345-357.

Van Bruggen, C., en F. Faqiri. 2015. Trends in beweiden en opstallen van melkkoeien en het effect op emissies naar lucht. CBS Webartikel 2015/02.

Van Bruggen, C., A. Bannink, C.M. Groenestein, J.F.M. Huijsmans, H.H. Luesink, S.M. van der Sluis, G.L. Velthof, en J. Vonk. 2015. Emissies naar lucht uit de landbouw 1990-2013. Berekeningen van ammoniak, stikstofoxide, lachgas, methaan en fijn stof met het model NEMA. WOt-technical report 46.

Van den Pol- van Dasselaar, A., P.W. Blokland, T.J.A. Gies, M.H.A. de Haan, G. Holshof, H.S.D. Naeff, en A.P. Philipsen. 2015. Beweidbare oppervlakte en weidegang op melkveebedrijven in Nederland. Wageningen UR Livestock Research Report 917.

Vonk, J., A. Bannink, C. van Bruggen, C.M. Groenestein, J.F.M. Huijsmans, J.W.H. van der Kolk, H.H. Luesink, S.V. Oude Voshaar, S.M. van der Sluis, en G.L. Velthof. 2016. Methodology for estimating emissions from agriculture in the Netherlands. Calculations of $\mathrm{CH}_{4}, \mathrm{NH}_{3}, \mathrm{~N}_{2} \mathrm{O}, \mathrm{NO}_{x}, \mathrm{PM}_{10}, \mathrm{PM}_{2.5}$ and $\mathrm{CO}_{2}$ with the National Emission Model for Agriculture (NEMA). WOt-technical report 53. 


\section{Bijlage 1 NH3-emissie voor melk- en kalfkoeien voor alle varianten}

\begin{tabular}{|c|c|c|c|c|c|c|c|c|c|c|c|c|}
\hline \multirow[b]{2}{*}{ Scenarios } & \multirow[b]{2}{*}{0} & \multicolumn{11}{|c|}{ Variant } \\
\hline & & 1 & 2 & 3 & 4 & 5 & 6 & 7 & 8 & 9 & 10 & 11 \\
\hline Uren in de weide & 0 & 4800 & 3600 & 1530 & 990 & 480 & 360 & 3150 & 1721 & 486 & 3600 & 990 \\
\hline \multicolumn{13}{|c|}{ Uitdoving in de stal: $2,61 \%$} \\
\hline Stal & 21,3 & 9,9 & 16,4 & 19,3 & 20,1 & 21,0 & 21,2 & 17,1 & 18,9 & 21,0 & 19,7 & 16,2 \\
\hline Opslag & 0,6 & 0,3 & 0,4 & 0,5 & 0,6 & 0,6 & 0,6 & 0,4 & 0,5 & 0,6 & 0,5 & 0,5 \\
\hline Beweiding & 0,0 & 4,0 & 2,9 & 1,2 & 0,7 & 0,3 & 0,2 & 2,5 & 1,3 & 0,3 & 3,8 & 0,6 \\
\hline Toediening & 24,1 & 13,6 & 15,7 & 20,7 & 21,7 & 22,6 & 22,8 & 16,8 & 20,1 & 22,6 & 18,9 & 17,5 \\
\hline Totaal & 46,0 & 27,8 & 35,4 & 41,7 & 43,2 & 44,6 & 44,8 & 36,8 & 40,8 & 44,6 & 42,9 & 34,7 \\
\hline \multicolumn{13}{|c|}{ Uitdoving in de stal: $1,3 \%$} \\
\hline Stal & 21,3 & 9,9 & 19,2 & 20,5 & 20,9 & 21,4 & 21,4 & 19,5 & 20,2 & 21,4 & 23,0 & 16,9 \\
\hline Opslag & 0,6 & 0,3 & 0,4 & 0,5 & 0,6 & 0,6 & 0,6 & 0,4 & 0,5 & 0,6 & 0,5 & 0,5 \\
\hline Beweiding & 0,0 & 4,0 & 2,9 & 1,2 & 0,7 & 0,3 & 0,2 & 2,5 & 1,3 & 0,3 & 3,8 & 0,6 \\
\hline Toediening & 24,1 & 13,6 & 15,2 & 20,5 & 21,6 & 22,6 & 22,7 & 16,3 & 19,9 & 22,6 & 18,2 & 17,3 \\
\hline Totaal & 46,0 & 27,8 & 37,6 & 42,7 & 43,8 & 44,9 & 45,0 & 38,8 & 41,9 & 44,9 & 45,5 & 35,2 \\
\hline \multicolumn{13}{|c|}{ Uitdoving in de stal: $0,65 \%$} \\
\hline Stal & 21,3 & 9,9 & 20,5 & 21,1 & 21,3 & 21,6 & 21,6 & 20,7 & 20,8 & 21,6 & 24,6 & 17,2 \\
\hline Opslag & 0,6 & 0,3 & 0,4 & 0,5 & 0,6 & 0,6 & 0,6 & 0,4 & 0,5 & 0,6 & 0,5 & 0,5 \\
\hline Beweiding & 0,0 & 4,0 & 2,9 & 1,2 & 0,7 & 0,3 & 0,2 & 2,5 & 1,3 & 0,3 & 3,8 & 0,6 \\
\hline Toediening & 24,1 & 13,6 & 14,9 & 20,4 & 21,5 & 22,5 & 22,7 & 16,1 & 19,8 & 22,5 & 17,9 & 17,3 \\
\hline Totaal & 46,0 & 27,8 & 38,7 & 43,2 & 44,1 & 45,1 & 45,1 & 39,7 & 42,4 & 45,1 & 46,8 & 35,5 \\
\hline
\end{tabular}


Wageningen Livestock Research

Postbus 338

$6700 \mathrm{AH}$ Wageningen

T 0317483953

info.livestockresearch@wur.nl

www.wur.nl/livestock-research

Wageningen Livestock Research

Rapport 983
De missie van Wageningen University \& Research is 'To explore the potential of nature to improve the quality of life'. Binnen Wageningen University \& Research bundelen Wageningen University en gespecialiseerde onderzoeksinstituten van Stichting Wageningen Research hun krachten om bij te dragen aan de oplossing van belangrijke vragen in het domein van gezonde voeding en leefomgeving. Met ongeveer 30 vestigingen, 5.000 medewerkers en 10.000 studenten behoort Wageningen University $\&$ Research wereldwijd tot de aansprekende kennisinstellingen binnen haar domein. De integrale benadering van de vraagstukken en de samenwerking tussen verschillende disciplines vormen het hart van de unieke Wageningen aanpak.

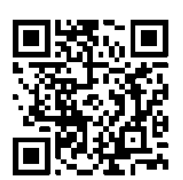

